\title{
Disleksi Hakkında Öğretmen Görüşleri ve Karşılaştıkları Sorunlar
}

\author{
Emine Balc1 ${ }^{1}$
}

$\ddot{\mathbf{O z}}$

Anahtar Sözcükler

Araștırmanın amacı, Türkiye'deki öğretmenlerin disleksiye ilişkin görüşlerini incelemek ve onların disleksiyle ilgili eğitim ihtiyaçlarını belirlemektir. Ankara İli Kalecik İlçesinde görev yapan bütün; sınıf, Türkçe, rehber, özel eğitim ve okul öncesi öğretmenleri çalıșmanın örneklemini olușturmuştur. Bu öğretmenlere veri toplama aracı olarak Yarı Yapılandırılmış Öğretmen Görüşme Formu ve Öğretmen Bilgi Formu uygulanmıştır. Elde edilen veriler içerik analizi yöntemi, yüzde ve frekans kullanılarak çözümlenmiș ve beș alt başlıkta incelenmiștir. Sonuç olarak öğretmenlerin üniversite eğitimlerinde disleksi hakkında yeterince bilgilendirilmedikleri ve aldıkları disleksi eğitimini yeterli bulmadıkları görülmüștür. Öğretmenlerin mesleklerine atandıktan sonra da disleksi hakkında yeterince bilgilendirilmedikleri ortaya çıkmıştır. Disleksi hakkındaki bilgilerinin kaynağı incelendiğinde ise ögretmenlerin \% 25'i bu kavramı, formal eğitim ortamlarında değil, Yerdeki Ylldızlar/Her Çocuk Özeldir adlı bir Hint Filmiyle öğrendiklerini belirtmişlerdir. Öğretmenlerin disleksi bilgi düzeylerinin yeterli olmadığı ve kendilerini yetersiz hissettikleri öğrenilmiştir. Öğretmenler aynı zamanda, disleksili bir öğrenciyle karșılașmaları durumunda; farkına varma, belirleme yönünde gerekli bilgi ve mesleki beceriye sahip olmadıkları yönünde görüş bildirmişlerdir. Bu öğrencilerin ihtiyaçlarını karşılayacak eğitim yöntemlerini bilmediklerini belirtmişlerdir. Öğretmenler disleksili öğrencileri için özel bir çalışma yapmamakta ve beden eğitimi, müzik gibi derslerde ya da öğle aralarına sıkıștırarak eğitim vermeye çalışmaktadır. Öğretmenler bu öğrencilerin eğitimlerinin kaynaştırma eğitiminden ziyade destek eğitim odaları aracılığıyla yapılması gerektiğini düşünmektedirler.

Disleksi

Okuma güçlüğü

Disleksili birey

Öğretmen görüşü

Öğretmen eğitimi

Makale Hakkında

Gönderim Tarihi

15 Ağustos 2018

Kabul Tarihi

19 Ocak 2019

Makale Türü

Araştırma Makalesi

DOI: $10.12984 /$ egeefd.453922

\section{Teachers' Opinions About Dyslexia and the Challenges They Face}

\section{Abstract}

The aim of this research is to examine the opinions of the teachers in Turkey about dyslexia and determine their training needs. Participants consisted of primary school, Turkish, guidance, specia education, and pre-school teachers serving in the Kalecik District of Ankara. The Semi-structured Teacher Interview Form and the Teacher Information Form were applied to these teachers as data collection tools. The obtained data was analyzed by using content analysis method, percent and frequency and examined in five sub-titles. As a result of the data analysis teachers were not informed enough about dyslexia in their university education and they did not think their dyslexia training was adequate. Teachers have not been sufficiently informed about dyslexia after they have been assigned to their profession. When the source of information about dyslexia is examined, $25 \%$ of the teachers stated that they learned dyslexia with an Indian film called Stars on the ground / Every child is special rather than formal education. Teachers also stated that they would not be able to identify them if they encountered a dyslexic student, and that they did not know about specific teaching methods to meet the needs of students with dyslexia. Teachers stated that they are not taking any special approach to work with dyslexic students, and they think that the training of these students should be done through resource rooms via individualized work rather than the inclusion programs.
Keywords

Dyslexia

Reading difficulties

Dyslexic individuals

Teacher opinion

Teacher training

Article Info

Received

August 15, 2018

Accepted

January 19, 2019

Article Type

Research Paper

Atıf: Balcı, E. (2019). Disleksi hakkında öğretmen görüşleri ve karşılaştıkları sorunlar. Ege Eğitim Dergisi, 20(1), $162-179$. doi:10.12984/egeefd.453922

1 (D) Alanya Alaaddin Keykubat Üniversitesi, Eğitim Fakültesi, Temel Eğitim Bölümü, Sınıf Eğitimi Anabilim Dalı, Türkiye, emine.balci@alanya.edu.tr. 


\section{Extended Abstract}

\section{Introduction}

Reading is not a naturally occurring skill in the individual. Reading is one of the most difficult and complex skills gained in human life. Anyone who does not have a neurological barrier can speak, but not everyone can read. This is because reading requires more sensitive visual, auditory and mental processes than speech. It is possible to encounter students who cannot read despite the fact that they do not have any mental, auditory or visual problems and have received adequate education. The difficulty experienced by these students is called dyslexia, and it has become an important area of research in the last century. Dyslexia is a very new concept in Turkey. For this reason, scientific research in the field of dyslexia in the country is currently very limited. For this reason, society has very limited knowledge about dyslexia. This study was conducted with teachers who work directly with individuals with dyslexia due to the lack of such studies. The aim of this research is to examine the opinions of the teachers in Turkey about dyslexia and determine their training needs.

\section{Method}

Survey research design, one of the descriptive research methods, was used in this study. Purposeful sampling method was utilized, and participants consisted of primary school, Turkish, guidance, special education, and preschool teachers serving in the Kalecik District of Ankara. The population of this study is the 72 teachers in the Kalecik District. 22 of them are male and 50 are females. 40 of the teachers are primary school teachers, 8 are Turkish teachers, 5 are special education teachers, 6 are psychological counseling and guidance teachers, and 13 are preschool teachers. Thus, all the participants have some sort of responsibility or interaction with students with dyslexia. In order to reveal the opinions of the teachers about the dyslexia, the following questions were asked:

1. Is the dyslexia training that teachers receive in college sufficient?

2. Are the dyslexia trainings that teachers receive in service training sufficient?

3. Where do teachers get their knowledge of dyslexia?

4. How are the teachers' knowledge levels of dyslexia?

5. How are teachers qualified for dyslexic education?

Semi-structured Teacher Interview Form which was developed by examining the national and international literature by the researcher was used as data collection tool. Expert opinion on the validity of the interview form was obtained. The content of the questions were revised, sub-probing suitability for coverage validity has been examined and necessary studies have been conducted in the language dimension. A preliminary study was conducted with twenty teachers who did not participate in the study group in order to measure the relevance level of the questions, and it was seen that the answers expected from the teachers were triggered by the questions. Responses were voice recorded with consent and teachers' answers were noted. Teachers were asked to provide additional clarifications. Thus, possible loss of data is prevented and compliance with the research questions of the data is preserved. The obtained information was transcribed and analyzed by content analysis method. Descriptive analysis and content analysis methods were used in the analysis of the data.

\section{Findings}

Significant findings were found in the study, which revealed teachers' dyslexia training needs. Only $40 \%$ of teachers were informed about dyslexia during their university education and this information was provided in only one or a few lessons. Mostly, the guidance teachers mentioned that they received a dyslexia course at the university. $95 \%$ of the teachers believe that the dyslexia training they have received in university education is not enough. As this study clearly shows, teachers are not adequately informed about learning difficulties, especially dyslexia, during their higher education.

It has emerged that teachers have not been sufficiently informed about dyslexia before they have been assigned to their profession. $97 \%$ of the teachers said that they were not informed about dyslexia in service trainings. 30 $\%$ of the teachers mentioned that they had never heard of dyslexia before. Twenty-five percent of teachers who did not receive enough dyslexia training in both their higher education and in-service training reported that they learned this concept from a movie. They mentioned that they were aware of this concept with an Indian movie entitled Taare Zameen Par/ Every Child is Special. The result of the research is quite interesting because teachers learn term of dyslexia through a movie they watch in social life or their research from the internet, not 
through teacher training in higher education or in-service training. As a result, it is understood that the teachers are left alone about dyslexia.

Dyslexia information, as seen in other questions asked by teachers in order to measure the level of dyslexia knowledge, is provided by the media. To the question of "What is dyslexia?" $25 \%$ of the teachers responded as "Dyslexia is seeing the words and letters in reverse like a mirror image." However, it is a myth that dyslexic individuals read backwards. The researches mention that there is no evidence that these individuals see and perceive the letters and the words backwards. Nevertheless, a common misconception is dominant in teachers that dyslexia is perceived as a difficulty in visual processing, rather than inadequacy of phonological processing. In addition, the proportion of teachers is also quite high who know the dyslexia as memory problem, mental disability, difficulty in speaking, carelessness, inability to learn, detailed thinking discomfort, and a temporary educational illness. Only $25 \%$ of teachers defined dyslexia correctly and $75 \%$ defined incorrectly or incompletely.

All the participants answered negatively to the question of "Do you think your dyslexia knowledge is sufficient?" This directly affects their ability to identify and support the dyslexic students they encounter. $65 \%$ of teachers confirmed that they would not be able to detect if they encountered a dyslexic student.

In this study, $100 \%$ of the teachers stated that they did not know the training methods for the dyslexic students and, all of the teachers said that they did not apply a different program to the dyslexic students. $80 \%$ of the teachers do not provide extra tutorial for these students. Other teachers are trying to tutor these students during physical education, music lessons, or lunch hours.

Teachers think that the education provided in the support training rooms or a combination of both the support training room and inclusive education for these students will be more useful.

Trainees have been able to hear the dyslexic concept but they do not have in-depth knowledge and do not know what to do with these students.

In this study, it was found that teachers did not follow a suitable education program for dyslexic individuals, they do not have adequate knowledge about the educational programs, and there is no standard in the education of these students.

\section{Discussion and Conclusion}

Dyslexia is a newly recognized concept in Turkey and has managed to attract the attention of educators in recent years. For this reason, scientific research about dyslexia is currently lacking. As seen in the current study, teachers' knowledge about dyslexia is quite limited. Education on Dyslexia should be included in teacher education in universities. Community awareness of dyslexia should be increased. Dyslexia should also be part of the curriculum work and individual education should be designed according to individual needs of each dyslexic student. 


\section{Giriş}

Öğrenmeyi olumlu ve olumsuz şekilde etkileyen çeşitli unsurlar bulunmaktadır. Bunlar öğrenen, öğrenme stratejileri, öğrenme malzemesi, öğrenme ortamıla ilgili etkenler olup, öğrenmeyi kolaylaştırır ya da zorlaştırırlar. Bu belirtilen unsurlarla iliş̧kili bir problemi olmayan her çocuğun, okul yaşamında başarılı olacağı düşünülür. Ancak belirgin bir problemi olmadığı hâlde okul başarısızlığı yaşayan pek çok çocuk vardır (Altuntaş, 2010; Bacanl1, 2004). Bu çocukların; zihinsel, görsel, işitsel, duygusal ve sosyal yönlerden herhangi bir problemi olmadığı hâlde; söz konusu çocuklar okuma, yazma, konuşma, işitme, görme ve aritmetik alanlarının birinde veya tümünde güçlükler yaşayabilmektedirler (Şenel, 1998). Disleksiyle ilk ilgilenen bilim adamlarından olan Morgan'ın da (1896) ifade ettiği gibi, bazen farklı alanlarda çok daha başarılı oldukları hâlde; belirli bir alanda problem yaşayan bu çocukların yaşadıkları sorunlara öğrenme güçlüğü denmektedir.

Öğrenme güçlüğü; sözel ya da yazılı dili anlama ya da kullanmayla ilgili süreçlerin bir ya da birkaçında yetersizlikleri olan ve bu yetersizliklere bağlı olarak dinleme, konuşma, okuma, yazma ya da matematiksel işlem yapma yeteneklerinde görülen sıkıntılardır. Öğrenme Gü̈clüğü 'nün; okuma bozukluğu (disleksi), yazılı anlatım bozukluğu (disgrafi), matematik bozukluğu (diskalkuli) gibi alt tipleri bulunmaktadır. Amerika Birleşik Devletleri'nde öğrenme güçlüğü çeken bireylerin yaklaşık \% 80`i disleksili olup diğer öğrenme güçlüğü çeken bireyler \% 20'lik bir alana sahiptir. Bu oranlardan da anlaşılacă̆ üzere disleksi ve öğrenme güçlüğü arasındaki bağ oldukça kuvvetlidir (Balc1, 2015; Lerner,1989; IDEA, 2004).

Okuma, bireyde doğal olarak meydana gelen bir beceri değildir. Okuma, insan hayatında kazanılan en zor ve karmaşık becerilerden biridir. Nörolojik olarak bir engel taşımayan herkes konuşabilirken, herkes okuyamamaktadır. Bunun nedeni, okumanın konuşmaya oranla daha hassas görsel, işitsel ve zihinsel süreçler gerektirdiğidir. Okumayı öğrenme bilişsel ve dilsel bir beceridir ve genelde dışarıdan destekle elde edilebilir. Dilsel ve bilişseldir çünkü dili işleme sürecinde beynin belli alanları, beynin hâlihazırda var olan bilişsel rezervleri okuma öğrenimi esnasında kullanılır. Bu nedenle okumayı öğrenmenin bilişsel-dilsel bir yapısı vardır. Amerika Birleşik Devletleri'nde (ABD) National Reading Panel 'in bulgularına göre yapilan araştırmalarda, okumayı öğrenirken beş temel beceri ele alınmaktadır. Bunlar; fonolojik farkındalık, ses bilgisi, akıcılık, kelime bilgisi ve anlamadır. Bu süreçlerden geçilerek, doğrudan, sistematik ve anlaşılır bir şekilde verilen okuma eğitimiyle bireyler okumayı öğrenmektedirler. Öğrencilerin çoğu bu süreci sorunsuz geçirirken, bir kısmı bu süreçte sorunlar yaşamaktadır. Bilinen bir problemi olmadığı hâlde okumada sorunlarla karşılaşıldı̆̆ bu duruma disleksi adı verilmektedir (Balcı, 2017).

Okuma yazma öğretimi okul öncesi dönemle başlamak üzere ilkokulda devam eden bir süreçtir. Türkiye'de okul öncesi dönemde erken okuryazarlık basamağıyla başlanıp seslerin hissedilmesi süreciyle alt zemin oturtulmaktadır. İlkokul birinci sınıf itibariyle okuma eğitimine tam anlamıyla başlanır. Bununla birlikte disleksi okulöncesi dönemde de tespit edilebilir. Erken okuryazarlık konusunda deneyimli ve bilgili eğitimciler bu öğrencileri tespit edebilme konusunda daha başarılı olmaları beklenir. Fakat Ergül ve diğerlerinin (2014) yaptığı çalı̧̧ma göstermektedir ki; okul öncesi öğretmenlerinin önemli bir bölümü erken okuryazarlık konusunda yeterli bilgi düzeyine sahip değildir ve sınıf içinde gerçekleştirdikleri uygulamalar erken okuryazarlık becerilerini desteklememektedir. Doğan (2013) ve Altuntaş (2010) ise sınıf öğretmenlerinin de disleksi konusunda kendilerini yeterli hissetmediklerinden bahsetmiştir.

Anadili İngilizce olan toplumlarda yapılan araştırmalara göre, disleksi, bu toplumların \% 3 ila \% 10'luk hatta bazen \% 20'leri bulan kesimini etkileyen bir alana sahiptir (Akhtar, 2008; Snowling, 2000). Etki alanı bu denli geniş olan disleksinin ise müdahale yöntemi eğitseldir. Bu öğrenciler ihtiyaçlarına uygun olarak hazırlanan okuma programlarıyla bu sıkıntılarının büyük bir oranda üstesinden gelmeleri mümkündür. Bu eğitsel tedavi sürecinde en büyük sorumluluk eğitimcilere düşmektedir. Öğrencilerinin okuma deneyimlerini dikkatle takip eden bir öğretmen, disleksili bireyin erken tanılanmasını sağlayacaktır. İlkokul 3. Sınıfa kadar tanılanmış, eğitsel müdahale süreci başlayıp başarılı sonuçlar almış bir disleksili öğrencinin diğer öğrencilerle eşit akademik başarı düzeylerine ulaşması ve psikolojik açıdan onlardan geri bırakılmaması çok önemlidir. Aksi takdirde, okuma öğrenememiş, sınıf ortalamasının çok gerisinde kalmış bir birey psikolojik olarak olumsuzluklarla karşılaşacak ve kendilerini yetersiz hissedeceklerdir. Hellendoorn ve Ruijssenaars (2000), disleksili çocukların yetişkinliklerinde bile devam eden sosyal ve duygusal sorunlarının olduğunu ve bu bireylerden ilkokuldaki deneyimleri pozitif olanların engellerini daha kolay kabullendiklerini söylemişlerdir. Riddick, Sterling, Farmer ve Morgan (1999) ise disleksililerin üniversite dönemlerinde bile düşük benlik algısına sahip olduklarından bahsetmektedir. Ingesson (2007) ise disleksinin bireylerde yarattığı olumsuz etki tanımlarken, erken teşhisin öneminden bahsetmektedir.

Humphrey'in (2003) de bahsettiği gibi disleksisi olan çocuklar için olumlu bir benlik hissi geliştirmede öğretmenlerin rolü oldukça önemlidir. Öğretmenler, yaptıkları çalışmalarla öğrencide akademik ilerlemeler yaratabilir (Exley, 2003). Bu nedenle eğitimcilerin disleksi hakkındaki farkındalıkları oldukça önemlidir. Buna rağmen öğretmenlerin disleksi farkındalığının zayıf olduğuna dair çalışmalarla karşılaşılmaktadır. Washburn, 
Joshi ve Binks-Cantrell (2011) öğretmenlerin, disleksi ile mücadele için gerekli bilgiye sahip olmadıklarını ortaya koymuştur. Aladwani ve Al Shaye (2012) ise Kuveyt'te yaptığı araştırmada, öğretmenlerin çoğunluğunun disleksili öğrencileri sınıfta belirleyebilmesi için gerekli eğitim, bilgi ve becerilerden yoksun olduğundan bahsetmektedir. Türkiye'de ise disleksi çok yeni bir kavram olup son zamanlarda eğitimcilerin dikkatini çekmektedir. Bu alanda akademik çalışmalar ise gün geçtikçe artmaktadır. Bu nedenle, Türkiye'deki eğitimcilerin disleksi farkındalığını ortaya koymayı amaçlayan bu çalışma, öğretmenlerin disleksiyle ilgili eğitim ihtiyaçlarını belirlemesi açısından önemlidir.

\section{Türkiye'de Disleksi Eğitimi}

Disleksi eğitimini başlatacak olan en önemli süreç bireyi teşhis etme sürecidir. Bu süreçte disleksili birey tanılanır ve disleksisinin düzeyi belirlenerek kişiye özgü eğitim planı hazırlanır. Özellikle erken tanılama bu güçlüğe karşı verilen mücadelede oldukça önemli bir role sahiptir. Schatschneider ve Torgesen (2004), erken teşhis ve fonolojik farkındalık alanında yapılacak erken müdahalenin, disleksi riski olan çocukların tedavisi için en önemli adımlardan biri olduğundan bahsetmektedir. Hurford, Schauf, Blaich, Moore ve Bunce'1n (1994), çalışmalarında bahsettiği gibi, erken teşhisle okuma güçlüğ̈nün önceden tespiti mümkündür. Bu nedenle eğitimciler, erken teşhis ve tanılama sürecine gereken önemi vermelidir.

Amerika ve Avrupa'da disleksi ile ilgili çalışmalar Türkiye'ye oranla çok daha önce başladığı için teşhis sürecinde de çok daha profesyonel adımlar atılmaktadır. Bu ülkelerde disleksili bireyler ülke genelinde kullanılabilecek ve pek çok çeşidi bulunan standart testlerle teşhis edilmekte ve güvenilir sonuçlar alınabilmektedir. Türkiye'de ise disleksili bireylere standart testlerle yapılan ön ve son değerlendirmelerden söz etmek mümkün değildir. Ülkede, bu bireylerin erken tanılanmasında da sorunlarla karşılaşıllmaktadır. Türkiye'de 3 , 4 ve 5. sinıfa hatta ortaokula kadar gelmiş fakat henüz okuyamayan ya da okumada güçlük yaşayan pek çok öğrencinin varlığı mevcuttur. Türkiye'de eğitim ortamlarında disleksinin tanılanmasından problemler yaşanmakla birlikte, okuma sorunu yaşayan bireylerin disleksili olup olmadığı, disleksiliyse hangi basamaklarda sorun yaşadığını tespit etmek için yapılan düzenli ve standart bir çalışmadan söz etmek mümkün değildir (Balcı, 2015).

$\mathrm{Bu}$ bireyleri tespit etmek için okullarda, öğretmenlerinin ve Rehberlik Araştırma Merkezleri'nin gözlemleri ve hazırladıkları değerlendirme araçları sonuçlarına dayanan daha sübjektif bir tanılama-teşhis süreci yaşanmaktadır. $\mathrm{Bu}$ da değerlendirme sonuçlarının güvenirliliğini etkilemektedir. Gür (2013) Türkiye'de uygulanan, disleksililerin belirlenmesine yönelik özel bir testin mevcut olmadığından bahsetmektedir. $\mathrm{Bu}$ kişilerin tespiti ve değerlendirilmesi, daha çok öğretmenlerin inisiyatifine bırakılmakta ve onların yaptıkları gözlem ve kişisel değerlendirmelerle bireydeki okuma güçlüğünün tespit edilmesi beklenmektedir. Oysaki Doğan (2013) yaptığı çalışmada, Türkçe ve sınıf öğretmenlerinin okuma güçlüğü olan öğrencileri belirlemede yetersiz kaldıklarını tespit etmiş̧ir.

Disleksi Türkiye'de toplumsal olarak yeni fark edilen ve eğitimcilerin dikkatini son yllarda çekmeyi başarabilmiş bir kavramdır. Bu nedenle ülkede, disleksi alanında yapılan bilimsel araştırmalar şuan için oldukça azdır. Yapılan çalışmaların azlığı, yetişmiş akademik personelin varlığını etkilemekte bu durum ise üniversitelerde, öğretmen adaylarına bu dersin programlarına konulmasını engellemektedir (Balcı, 2015). Sonuç olarak, bu alanda bilgi sahibi olmayan öğretmenlerin meslekleri içerisinde, kendilerini bu konuda eksik hissetmelerine neden olmaktadır. Doğan (2013), Türkçe ve sınıf öğretmenlerinin okuma güçlüğü konusunda yeterli bilgiye sahip olmadıkları üzerinde durmuştur. Çuhadar (2006) ise Türkiye'de 1-5. sınıflar arasında eğitim veren öğretmenlerin, özel eğitim öğrencilerinin eğitimlerinde hazırlamaları gereken Bireyselleştirilmiş Eğitim Programlarının (BEP) önemini kabul etmelerine rağmen \% 77.8'inin BEP yapmadıklarından bahsetmiștir. Ünal (2010), ise sınıf öğretmenlerinin, bu öğrencilerin eğitimine yeterli zaman ayıramadıkları ve BEP'leri tam olarak uygulamadıklarından bahsetmektedir. Öğretmenlerin değerlendirme ve uygulama basamağında yaşadıkları bu problemlerin ası nedeni bu alanda eğitim eksiklerinin olmasından kaynaklandığı düşünülmektedir. Eğitim uygulamalarına ilişkin yeterince bilgi sahibi olmadıkları için bu öğrencilere gereken eğitimi verememektedirler. Baydık, Ergül ve Kudret (2012) çalışmalarında; sınıf öğretmenlerinin okuma güçlüğü konusunda hizmet içi eğitim almaları gerektiğini işaret etmiştir. Cankaya ve Korkmaz (2012) yaptıkları çalışmada, sınıf öğretmenlerinin kaynaştırma eğitim uygulamaları konusunda aldıkları eğitimin yetersiz olduğunu ifade etmişlerdir. Sığırtmaç, Hoş ve Abbak (2011), okul öncesi öğretmenlerinin kaynaştırma eğitimlerine ilişkin bilgi yetersizliklerinin olduğundan ve bu yetersizliklerinin kaynaklarının ise kişisel yetersizlikler ve lisans eğitimleri sırasında yeterince özel eğitim dersi ve uygulaması almamış olmalarından kaynaklandığından bahsetmektedir.

Sonuç olarak öğretmenlerinin bu alandaki yetersizlikleri; bu öğrencilerin gözden kaçmasına neden olmakta, okuma öğrenemeyen ya da okumakta zorlanan bireyleri ve onların ailelerini eğitim hayatında pek çok sorun ile baş başa bırakmaktadır. Türk eğitim sistemi bünyesinde yer alan öğretmenlerin disleksiye ilişkin problemlerinin tespit edilmesi, bu problemlerin giderilmesi ve bu öğrencilere verilecek eğitimin kalitesini arttırmak açısından 
atılabilecek en önemli adımlardan biridir. Bu nedenle mevcut çalışma ile öğretmenlerin disleksiyle ilgili eğitim ihtiyaçlarını belirlemek hedeflenmektedir.

$\mathrm{Bu}$ çalışmada, öğretmenlerin disleksiye ilişkin görüşlerini incelemek ve onların disleksiyle ilgili eğitim ihtiyaçlarını belirlemek amacıyla hazırlanmıştır. Bu amaca ulaşmak için şu sorulara cevap aranmışıı:

1. Öğretmenlerin üniversitede aldıkları disleksi eğitimleri yeterli mi?

2. Öğretmenlerin hizmet içi eğitimlerde aldıkları disleksi eğitimleri yeterli mi?

3. Öğretmenler var olan disleksi bilgisine nereden ulaştılar?

4. Öğretmenlerin disleksi bilgi düzeyleri nasıldır?

5. Öğretmenlerin disleksili öğrencilere verilecek eğitimle ilgili yeterlilikleri nasıldır?

Yöntem

\section{Araştırmanın Deseni}

Araştırmada; betimsel araştırma modelinden tarama modeli kullanılmıştır. Tarama modeli, geçmiş̧e veya halen var olan bir durumu var olduğu şekliyle betimlemeyi amaçlayan araştırma yaklaşımıdır (Karasar, 2000). Tarama modeli araştırmalar ile öğretmenler, denetmenler ve yöneticiler hakkında bilgi toplamak, bunları değişsenlerle olan ilişkileri yönünden incelemek kolay olmaktadır (Kaptan, 1998). Bu araştırma öğretmenlerin disleksiye ilişkin görüşlerini tespit etmek amacı taşıdığı için tarama modeli çalışmanın ruhuna uygun düşmektedir. Araştırmanın verileri ise nitel araştırma yöntemlerinden yarı yapılandırılmış görüşme tekniği ile toplanmıştır.

\section{Örneklem}

Araştırmanın çalışma grubunu amaçlı örnekleme yoluyla seçilen Ankara İli Kalecik İlçesi’nde görev yapan bütün; sınıf, Türkçe, rehber, özel eğitim ve okul öncesi öğretmenleri oluşturmaktadır. Bu branşlardan sınıf ve okul öncesi öğretmenleri; erken okuryazarlık becerisi, okumaya yazmaya geçiş, okuma yazma yeterliği açısından önemli olduğu için seçilmiştir. Türkçe öğretmenleri; dil ve anlatım, okuma, okuduğunu anlama becerilerini desteklemek için çalıştıkları için çalışma grubuna dâhil edilmiştir. Rehber öğretmenleri, bu öğrencileri belirme süreci ve sonrasında sorumlulukları olan öğretmenlerdir. Özel eğitim öğretmenleri ise destek hizmetler alanlarında özellikle tanı sonrası süreçte akademik destek vermekle sorumlu olduğundan çalışmanın parçasını oluşturmaktadırlar. Araştırma grubunu, belirlenen branşlardan toplam 72 öğretmen oluş̧urmuştur. Bunların 22'si erkek ve 50'si kadındır. Öğretmenlerin 40'1 sınıf öğretmeni, 8'i Türkçe öğretmeni, 5'i özel eğitim öğretmeni, 6's1 psikolojik danışmanlık ve rehberlik öğretmeni, 13'ü ise okul öncesi öğretmenidir. Böylece ilçede, disleksi ile doğrudan ilişkisi olduğu düşünülen branşlardaki tüm öğretmenlere ulaşılmıştır. Mesleki hizmet süresi 1-5 yıl arasında 27, 6-10 yıl arasında 36, 11-15 yıl arasında 4, 16-20 y1l arasında 2, 20 yıldan fazla ise 3 öğretmen bulunmaktadır. Öğretmenlerin 2'si ön lisans (sınıf öğretmeni), 64'ü lisans ve 6'sı lisansüstü (1 okul öncesi, 1 Türkçe, 2 rehber öğretmen, 2 sınıf öğretmeni) mezunudur. Çalışma grubunun frekans ve yüzde dağılımları Tablo 1 'de verilmiştir.

Tablo 1

Çalışma Grubunun Frekans ve Yüzde Dağılımları

\begin{tabular}{|c|c|c|c|}
\hline & & $f$ & $\%$ \\
\hline \multirow{2}{*}{ Cinsiyet Bilgileri } & Kadın & 50 & 69.4 \\
\hline & Erkek & 22 & 3.5 \\
\hline \multirow{5}{*}{ Mesleki Hizmet Süresi } & $1-5$ & 27 & 37.5 \\
\hline & $6-10$ & 36 & 50 \\
\hline & $11-15$ & 4 & 5.5 \\
\hline & $16-20$ & 2 & 2.7 \\
\hline & 20 yıldan fazla & 3 & 4.1 \\
\hline \multirow{3}{*}{ Öğrenim Durumu } & Ön Lisans & 2 & 2.7 \\
\hline & Lisans & 64 & 88.8 \\
\hline & Lisansüstü & 6 & 8.3 \\
\hline \multirow{5}{*}{ Branş } & Sinif & 40 & 55.5 \\
\hline & Türkçe & 8 & 11.1 \\
\hline & Özel Eğitim & 5 & 6.9 \\
\hline & Psikolojik Danışmanlık ve Rehberlik & 6 & 8.3 \\
\hline & Okul Öncesi & 13 & 18 \\
\hline
\end{tabular}




\section{Veri Toplama Araçları}

Öğretmenlerin disleksiye ilişkin görüşlerini ortaya koymak amacıyla, veri toplama aracı olarak, araştırmacı tarafından ulusal ve uluslar arası literatür taranarak geliştirilen Yarı Yapılandırılmış Öğretmen Görüşme Formu kullanılmıştır. Görüşme Formunu uygulamadan önce, öğretmenlerin demografik bilgilerini elde etmek amacıyla Öğretmen Bilgi Formu kullanılmıştır. Ankara İli Kalecik İlçe Milli Eğitim Müdürlüğü'nden formun uygulanabilmesi için gerekli izinler alınmış ve ilçede görev yapan, disleksi ile doğrudan ilgisi bulunan bütün öğretmenler listelenmiştir. Listelenen 72 öğretmene çalışmada ulaşılmıştır.

Görüş̧e formunun; geçerliği konusunda uzman görüşü alınmıştır. Soruların içeriği gözden geçirilmiş, kapsam geçerliliği için alt probleme uygunlukları incelenmiş ve dil açısından gerekli düzenlemeler yapılmıştır. İkinci aşamada; soruların amaca hizmet etme düzeyine bakılması amacıyla çalışma grubuna katılmayan, tüm branş bazından 4'er, toplamda 20 öğretmenle ön çalışma yapılmıştır ve öğretmenlerden beklenen cevapların alındığı görülmüştür.

Görüşme Formu beş bölümden oluşmaktadır. Her bölümde hedeflenen alt problemlere ait önceden belirlenmiş sorulara yer verilmiştir. Görüşmenin doğası bozulmadan görüşmeyi genişletecek her katılımcıya göre değissen ek sorular araştırmacı tarafindan sorulmuştur. Birinci bölümde, öğretmenlerin üniversitede aldıkları disleksi eğitimlerinin yeterliliğini ölçmek amacıyla dört ana soruya yer verilmiş̧tir. İkinci bölümde üç soruyla, öğretmenlerin hizmet içi eğitimlerde aldıkları disleksi eğitimlerinin yeterliliğini ölçmek amaçlanmıştır. Üçüncü bölümde sorulan bir soruyla öğretmenlerin var olan disleksi bilgisine nereden ulaştıklarına dair bilgi edinilmeye çalışılmıştır. Dördüncü bölümde, öğretmenlerin disleksi bilgi seviyesine ilişkin dört soru sorulmuştur. Beşinci bölümde, dört görüşme sorusu ile öğretmenlerin disleksili öğrencilere verilecek eğitimle ilgili yeterlilikleri ölçülmeye çalışılmıştır.

\section{Veri Analizi}

Veriler toplanırken, randevu talep edilmiş ve görüşme yapımına uygun bir ortam seçilmiştir. Ses kayıt cihazı ve not alma teknikleri ile kayıtlar alınmış ve öğretmenlerin cevapları not edilmiştir. Öğretmenlere gerektiğinde ek sorular sorulmuş ve açıklamalar yapması istenmiştir. Böylece olası veri kaybının önlenmesi sağlanmış ve verilerin araştırma sorularına uyumu korunmuştur. Elde edilen bilgiler bilgisayar ortamında metin haline dönüştürülmüş, bu veriler içerik analizi yöntemiyle çözümlenerek yorumlanmıştır. Elde edilen veriler yorumdan uzak bir şekilde hem araştırmacı hem de nitel araştırma konusunda uzman bir öğretim üyesi ile ayrı ayrı kodlanmış ve karşılaştırma yapılarak tutarlık oranı hesaplanmıştır. Belirlenen başlıklara göre veriler işlenmiş ve doğrudan alıntılarla bulgular açıklanmıştır. Ses kayıtları ve kayıtların yazılı notları güvenirliği arttırmak amacıyla başka araştırmacılar tarafından incelenmiş ve tutarlılık sağlanmıştır.

Araştırmanın analizinde betimsel analiz ve içerik analizi yöntemleri kullanılmıştır. Betimsel analiz; elde edilen verilerin daha önceden belirlenen temalara göre özetlenip yorumlandığı, görüşülen bireylerin görüşlerinin çarpıcı bir biçimde yansıtmak amacıyla sık sık doğrudan alıntıların kullanıldığı ve elde edilen sonuçların neden- sonuç ilişkileri çerçevesinde yorumlandığı analiz tekniğidir (Yıldırım ve Şimşek, 2003). İçerik analizi sırasında güvenirliği belirlemek amacıyla kodlayıcılar arası tutarlılı̆g bakılmıştır. Bu amaçla yansız olarak seçilen iki katılımcının ham veri haline dönüştürülen kayıtları araştırmacı tarafından bağımsız olarak kodlanmıştır. Her iki katılımcının her soruya verdikleri cevaplar tek tek incelenmiş ve görüş̧e kodlama anahtarı oluşturulmuştur. Her iki katılımcının görüşme kodlama anahtarları karşılaştırılmış ve uyuşum yüzdelerinin oranının \% 70'den fazla olup olmadığına bakılmıştır. Bu çalışmada içerik analizinde güvenirliğin belirlenmesi amacıyla uyuşum yüzdesi formülü kullanılmıştır. Uyuşum yüzdesi (Agreement percentage) Güvenirlik = Görüş birliği $/$ (Görüşs Birliği + Görü̧s Ayrllığı) x 100 formülü kullanılarak hesaplanmıştır (Miles ve Huberman, 1994). Yıldırım ve Şimşek'e (2003) göre, güvenirlik hesaplamasındaki uyuşum yüzdesi $\% 70$ olduğunda güvenirlik yüzdesine ulaşılmış kabul edilir. Çalışmada, tüm sorular için genel uyuşum düzeyi ise 0.90 olarak hesaplanmıştır.

\section{Bulgular}

\section{Öğretmenlerin Üniversitede Aldıkları Disleksi Eğitimlerinin Yeterliliği}

Öğretmenlerin yükseköğrenimleri sırasında aldıkları disleksi eğitimlerini ortaya çıkarmak amacıyla "Üniversite eğitiminiz sırasında disleksi alanında bilgilendirildiniz mi?" sorusu sorulmuştur. Bu soruya verdikleri cevaplar Tablo 2'deki gibidir: 
Tablo 2

Öğretmenlerin Üniversite Ĕ̆itimleri Strasında Disleksi Hakkında Bilgilendirilmeleri

\begin{tabular}{lcc}
\hline & $f$ & $\%$ \\
\hline Üniversitede Disleksi Eğitimi Alanlar & 29 & 40.2 \\
Üniversitede Disleksi Eğitimi Almayanlar & 43 & 59.7 \\
\hline
\end{tabular}

Öğretmenlerin \% 40 oranında üniversitede bilgilendirildikleri sonucu çıkmakla beraber, "Nasıl bilgilendirildiniz?" sorusuna verdikleri cevap yoğun bir şekilde; "Özel eğitim dersi işlenirken bir/ birkaç ders saatinde kisa sürede işledik" şeklinde olmuştur. Verilen diğer cevaplar ise şu şekildedir:

Problemin tanımı ile ilgili kısa bilgilendirme yapıldı (1 haftalık) ayrıntılı eğitim almadım (Rehber Ögretmen-RÖ)

Özel ĕgitime giriş dersinde 1 dönemde bir konu olarak anlatıldı (Özel Ĕgitim Öğretmeni-ÖEÖ)

Seçmeli ders olarak aldı̆̆ım kaynaştırma ĕgitimi dersinde geçti (Okul Öncesi Öğretmeni-OÖÖ)

Özel ĕgitim dersinde üzerinde en çok durulan konuydu 3 hafta olmasına rağmen yeterli bilgilendiğimi hissetmiyorum (Sinıf Öğretmeni-SÖ).

Üniversitede eğitim aldıklarını söyleyen öğretmenlerin branş bazında değerlendirmesi ise Tablo 3 'teki gibidir:

Tablo 3

Disleksi Hakkında Üniversitede Bilgilendirilen Öğretmenlerin Branş Bazında Değerlendirilmesi

\begin{tabular}{lcc}
\hline & $f$ & $\%$ \\
\hline Sinıf Öğretmeni & $14 / 40$ & 35 \\
Rehber Öğretmen & $5 / 6$ & 83.3 \\
Okul Öncesi Öğretmeni & $8 / 13$ & 61.5 \\
Türkçe & $0 / 8$ & - \\
Özel Eğitim Öğretmeni & $2 / 5$ & 40 \\
\hline
\end{tabular}

Çalışmaya katılan 6 rehber öğretmeninin 5'i (\% 83), 13 okul öncesi öğretmeninin 8'i (\% 61), 40 sınıf öğretmeninin 14'ü (\% 35) ve 5 özel eğitim öğretmeninin 2'si (\% 40) disleksiyle ilgili üniversitelerinde eğitim aldığından bahsederken, 8 Türkçe öğretmeninin tamamı bu eğitimi almadıklarını söylemişlerdir.

Öğretmenlere sorulan 'Üniversitede aldığınız eğitimlerin sizi disleksi konusunda yeterince bilgilendirdiğini düşünüyor musunuz?' sorusuna verdikleri cevaplar ise Tablo 4'teki gibidir:

Tablo 4

Öğretmenlerin Üniversitedeki Disleksi Eğitimini Yeterli Bulma Durumları

\begin{tabular}{lcc}
\hline & $f$ & $\%$ \\
\hline Aldıkları eğitimi yeterli bulanlar & $3 / 72$ & 4.1 \\
Aldıkları eğitimi yetersiz bulanlar & $69 / 72$ & 95.8 \\
\hline
\end{tabular}

Öğretmenlerin yaklaşık yarısı bir önceki tabloda üniversitede disleksi eğitimi aldıklarından bahsederken, \% 95.8’i bu eğitimin yeterli olmadığından bahsetmektedirler. Sadece 2 rehberlik ve 1 okul öncesi öğretmeni aldıkları eğitimin yeterli olduğu düşüncesindedir.

$\mathrm{Bu}$ öğretmenlere "Sizce üniversite eğitimi sırasında disleksiyle ilgili bu eğitim, öğretmen adaylarına nasıl verilmelidir?" sorusuna öğretmenler yoğun olarak uygulamalı ve birebir disleksili bir öğrenci üzerinden verilecek bir eğitimden bahsederken bu dersin zorunlu ve tüm branşlarda ortak verilmesi gerektiğini düşünmektedirler. Bu soruya verdikleri cevaplara örnekler aşağıdaki gibidir:

Daha ayrıntılı ve uygulamaya yönelik bir dersle verilmeli (öğretmenlerin yoğun olarak verdikleri cevap). Teorik ezberlenir ve ögrenciye müdahaleyi güçleştirir ayrıca unutulabilir. Yaparak göstererek verilen ĕgitim daha kalıcı olur (RÖ)

Konunun uzmanından alınan ve teorikte kalmayan bir ĕgitimle...(SÖ)

Özel ĕgitim dersi her branşın ders programına zorunlu ders kapsamında eklenmeli (RÖ)

Kaynaştırma ĕgitimi dersi içinde yer almalı ve bu ders tüm branşlarda zorunlu ve ortak ders olmall (SÖ)

Deneyimli ögretmenlerden yararlanılabilir (OÖÖ) 
Akademisyenler bu konu hakkında uzmanlaşmalı ve aday ögretmenlerin bu alana yönelik ihtiyaçlarına cevap verecek şekilde olmalı (SÖ)

Üniversitedeki ders saati bu konu için yetersiz daha kapsaml ve sorunlara çözüm bulabilecek bir eğitim verilmeli (ÖEÖ)

Bu ders en azından seçmeli olarak verilebilir (SÖ)

Farkindalık kazanabilmek için bu sorunu yaşamış bireylerin tecrübeleri aracıllğıyla bir eğitim verilmeli (OÖÖ)

Örnek ögrrenci videosu derse getirilerek bu ögrenci üzerinden ders anlatılmalı (SÖ)

Özellikle sinıf ögretmenlerine ayrı bir ders olarak verilebilir. Bu ögrencilere verilecek eğitimin nasll olmasl gerektiği konusunda adaylar bilgilendirilmelidir (SÖ)

Aday ögretmenlere disleksi araşttrma konusu olarak derste verilmelidir (SÖ)

Toplum hizmeti uygulamalarını kapsayan bir eğitimle verilebilir (TÖ)

\section{Öğretmenlerin Hizmet içi Eğitimlerde Aldıkları Disleksi Eğitimlerinin Yeterliliği}

Öğretmenlerin mesleklerine atandıktan sonra aldıkları hizmet içi eğitimlerin, onlarda yarattığı disleksi farkındalığını ölçebilmek amacıyla "Disleksi ile ilgili öğretmenlik hayatınız boyunca hiç hizmet içi eğitim aldınız mı?" sorusu sorulmuştur ve verdikleri cevap Tablo 5’teki gibidir:

Tablo 5

Öğretmenlerin Hizmet İçi Eğitimleri Strasında Disleksi Hakkında Bilgilendirilmeleri

\begin{tabular}{lcc}
\hline & $f$ & $\%$ \\
\hline Hizmet içi eğitim alanlar & 2 & 2.7 \\
Hizmet içi eğitim almayanlar & 70 & 97.2 \\
\hline
\end{tabular}

Öğretmenler \% 97.2 oranında disleksi ile ilgili hizmet içi eğitim almadıklarından bahsetmektedir. Hizmet içi eğitim aldığını söyleyen bir rehber ve bir sınıf öğretmeni ise sadece 2 saatten oluşan bir eğitim verildiğinden ve bu hizmet içi eğitimin kendilerini yeterince bilgilendirmediğinden bahsetmektedir.

\section{Öğretmenlerin Var Olan Disleksi Bilgilerinin Kaynağı}

Öğretmenlerde var olan disleksi bilgisinin kaynağını öğrenebilmek amacıyla "Disleksiyle ilgili bilgiye nereden sahip oldunuz?" sorusu sorulmuştur ve verilen cevaplar Tablo 6'da sıralanmıştır.

Tablo 6

Ögretmenlerin Var Olan Disleksi Bilgilerinin Kayna $\breve{l}$

\begin{tabular}{lcc}
\hline & $f$ & $\%$ \\
\hline Üniversite & 12 & 16.6 \\
Internet & 10 & 13.8 \\
Kitap & 3 & 4.1 \\
Film & 18 & 25 \\
Gönüllü Katılınan Seminer & 2 & 2.7 \\
Rehberlik Araştırma Merkezi (RAM) & 1 & 1.3 \\
Meslektaş & 1 & 1.3 \\
Disleksili Tanıdık & 1 & 1.3 \\
Makale & 1 & 1.3 \\
Hizmetiçi Eğitim & 1 & 1.3 \\
Disleksi Hakkında Bilgim Yok & 22 & 30.5 \\
\hline
\end{tabular}

Öğretmenlerin \% 30’u disleksiyi daha önce duymadıklarını söylerken, \% 25'i daha önce izledikleri Yerdeki Ylldızlar/Her Çocuk Özeldir adlı bir Hint Filmiyle bu kavram hakkında haberdar olduklarından bahsetmişlerdir. \% 16'sı üniversitede bu kavramı öğrendiklerini, \% 13'ü ise internetten kendi araştırmaları sonucu bu kavrama ulaştıklarını söylemişlerdir. Bu öğretmenler, disleksili bir öğrenciyle karşılaştıkları için araştırma ihtiyacı hissettiklerini, bu nedenle internet üzerinde yaptığı çalışmanın kendisini disleksiyle karşılaştırdığından söz etmişlerdir. 


\section{Öğretmenlerin Disleksi Bilgi Düzeyleri}

Öğretmenlerin disleksi bilgi düzeylerini ölçmek amacıyla sorulan "Sizce disleksi nedir?" sorusuna verdikleri cevaplar Tablo 7'deki gibidir:

Tablo 7

Ögretmenlere Göre Disleksi Tanımı

\begin{tabular}{|c|c|c|c|c|c|c|c|}
\hline & & Sinif & $\begin{array}{c}\text { Okul } \\
\text { Öncesi }\end{array}$ & Türkçe & Rehberlik & $\begin{array}{c}\text { Özel } \\
\text { Eğitim }\end{array}$ & Toplam \\
\hline $\begin{array}{l}\text { Ayna Görüntüsü (Harfleri } \\
\text { ve Cümleleri Ters Görme) }\end{array}$ & $f$ & $\begin{array}{c}11 \\
15.27\end{array}$ & $\begin{array}{c}6 \\
8.33\end{array}$ & $\begin{array}{c}1 \\
1.38\end{array}$ & $\begin{array}{c}1 \\
1.38\end{array}$ & $\begin{array}{l}- \\
-\end{array}$ & $\begin{array}{c}19 \\
26.3\end{array}$ \\
\hline Hafiza Problemi & $\underset{\%}{f}$ & $\begin{array}{c}2 \\
2.77\end{array}$ & $\begin{array}{l}- \\
-\end{array}$ & $\begin{array}{l}- \\
-\end{array}$ & $\begin{array}{l}- \\
-\end{array}$ & $\begin{array}{c}2 \\
2.77\end{array}$ & $\begin{array}{c}4 \\
5.5\end{array}$ \\
\hline Zihinsel Bir Engel & $f$ & $\begin{array}{c}1 \\
1.38\end{array}$ & $\begin{array}{c}1 \\
1.38\end{array}$ & $\begin{array}{l}- \\
-\end{array}$ & $\begin{array}{l}- \\
-\end{array}$ & $\begin{array}{l}- \\
-\end{array}$ & $\begin{array}{c}2 \\
2.7\end{array}$ \\
\hline $\begin{array}{l}\text { Konuşmada Yaşanan } \\
\text { Güçlük }\end{array}$ & $\underset{\%}{f}$ & $\begin{array}{c}3 \\
4.1\end{array}$ & - & - & $\begin{array}{c}1 \\
1.38\end{array}$ & - & $\begin{array}{c}4 \\
5.5\end{array}$ \\
\hline Öğrenememe & $\begin{array}{l}f \\
\%\end{array}$ & $\begin{array}{c}8 \\
11.1\end{array}$ & $\begin{array}{c}5 \\
6.9\end{array}$ & $\begin{array}{c}4 \\
5.5\end{array}$ & $\begin{array}{c}1 \\
1.38\end{array}$ & $\begin{array}{l}- \\
-\end{array}$ & $\begin{array}{l}18 \\
25\end{array}$ \\
\hline Dikkatsizlik & $\underset{\%}{f}$ & $\begin{array}{c}1 \\
1.38\end{array}$ & $\begin{array}{l}- \\
-\end{array}$ & $\begin{array}{l}- \\
-\end{array}$ & $\begin{array}{l}- \\
-\end{array}$ & $\begin{array}{l}- \\
-\end{array}$ & $\begin{array}{c}1 \\
1.38\end{array}$ \\
\hline $\begin{array}{l}\text { Okuma ve Yazmada } \\
\text { Güçlük }\end{array}$ & $\begin{array}{l}f \\
\%\end{array}$ & $\begin{array}{c}9 \\
12.5\end{array}$ & $\begin{array}{c}1 \\
1.38\end{array}$ & $\begin{array}{c}2 \\
2.77\end{array}$ & $\begin{array}{c}3 \\
4.1\end{array}$ & $\begin{array}{c}3 \\
4.1\end{array}$ & $\begin{array}{l}18 \\
25\end{array}$ \\
\hline $\begin{array}{l}\text { Geçici Bir Eğitim } \\
\text { Hastalığ }\end{array}$ & $\begin{array}{l}f \\
\%\end{array}$ & $\begin{array}{l}- \\
-\end{array}$ & $\begin{array}{l}- \\
-\end{array}$ & $\begin{array}{c}1 \\
1.38\end{array}$ & $\begin{array}{l}- \\
-\end{array}$ & $\begin{array}{l}- \\
-\end{array}$ & $\begin{array}{c}1 \\
1.38\end{array}$ \\
\hline $\begin{array}{l}\text { Detaylı Düşünme } \\
\text { Rahatsızlığ1 }\end{array}$ & $\underset{\%}{f}$ & $\begin{array}{c}1 \\
1.38\end{array}$ & $\begin{array}{l}- \\
-\end{array}$ & $\begin{array}{l}- \\
-\end{array}$ & $\begin{array}{l}- \\
-\end{array}$ & $\begin{array}{l}- \\
-\end{array}$ & $\begin{array}{c}1 \\
1.3\end{array}$ \\
\hline Bilmiyorum & $\begin{array}{l}f \\
\%\end{array}$ & $\begin{array}{c}4 \\
5.5\end{array}$ & $\begin{array}{l}- \\
-\end{array}$ & $\begin{array}{l}- \\
-\end{array}$ & $\begin{array}{l}- \\
-\end{array}$ & $\begin{array}{l}- \\
-\end{array}$ & $\begin{array}{c}4 \\
5.5\end{array}$ \\
\hline
\end{tabular}

Öğretmenlerin \% 26'sı disleksiyi ayna görüntüsü adı verilen "Harfleri, heceleri, kelimeleri ve cümlenin tamamını ters algılayarak görme, okuma rahatsızlı̆gı" olarak tanımlamaktadır. Bu öğretmenlerin 11'i (2'si lisansüstü, 1'i ön lisans) sınıf öğretmeni (\% 15), 6'sı okul öncesi (\% 8), 1'i Türkçe (\% 1.3) ve 1'i Rehber öğretmendir (\% 1.3). Bu öğretmenlerin verdikleri cevaplardan birkaçı şu şekildedir;

Çocuğun harfleri, rakamları, sayıları ters yazması. Yani ayna tutulduğunda yazının düzelmesidir (OÖÖ)

Harfleri saylları ters görme, hareket ediyor gibi görmesidir (OÖÖ)

Çocukların harfleri olduğu gibi değil de farklı şekilde algılaması ve okuma-yazmada da bu şekilde davranılmasıdir (OÖÖ)

Harflerin, rakamların tersten yazılması, yaptı̆̆ resimleri simetrisi gibi yapmasıdır (SÖ) şeklinde cevaplar vermişlerdir.

Kelime ve sözcüklerin tersten okunmasıdır (SÖ)

Öğretmenlerin \% 25'i ise disleksiyi öğrencinin öğrenememesi, akademik olarak geride kalma durumu olarak tanımlamaktadırlar. Bu öğretmenlerden 8'i sınıf öğretmeni (\% 11.1), 5'i okul öncesi (\% 6.9), 4'ü Türkçe (\% 5.5), 1'i rehber öğretmendir (\% 1.3). Bu kategoride değerlendirilen öğretmenlerin verdikleri cevaplar ise aşağıdaki gibidir:

Akademik olarak ögrencinin yaşadlŭg, öğrenmedeki güçlüktür. Sinıf seviyesine ait öğrenme düzeyinin gerisinde olmasıdır (SÖ)

Bireye özgü beynin bazı bölümlerinde yaşanan sıkıntılar sonucu öğrenmenin zorlaşmasıdır. Öğrenme güçlüğ̈̈dür kisaca (SÖ)

Öğrenme bozukluğu, öğrencinin öğrendiklerini yanlış öğrenmesidir (TÖ)

Normal zekâya sahip çocuğun yaşına ve zekâsına uygun olarak öğrenememesidir (RÖ) 
Bu cevaplardan da anlaşılacağı üzere öğretmenler ögrenme güçlüğü kavramını akademik olarak tüm alanlarda yaşanan öğrenememe problemi olarak algılamakta ve genellemektedirler.

Öğretmenlerin \% 25'i ise doğruya yakın cevap vererek disleksiyi okuma ve yazmada yaşanan güçlük olarak tanımlamışlardır. Bu öğretmenlerin 9'u (1'i lisansüstü, 1'i ön lisans) sınıf öğretmeni (\% 12.5), 1'i okulöncesi (\% 1.3), 2'si Türkçe (\% 2.7), 3'ü rehberlik (4.1) ve 3'ü özel eğitim öğretmenidir (4.1). Öğretmenler içinde, 2 Rehberlik ve 1 Sınıf öğretmeninin yaptığı ve disleksinin en iyi tanımlandığı cevaplar ise şunlardır:

Okuma, yazma, matematiksel beceriler gibi konularda bozulmanın eşlik ettiği öğrenme güçlügüdür (RÖ)

Sadece okuma alanında değil, dinleme, konuşma ve matematiksel becerilerde bile görülebilen, zekâ geriliği ile ilişkilendirilmemesi gereken bir takım gelişimsel ya da sonradan oluşan aksakliklardır (SÖ)

Çocuğun yaşıtlarından farklı olarak yaşadı̆̆ı, okuma, yazma, aritmetik gibi becerilerde kendini gösteren özel ögrenme güçlüğüdür (RÖ)

Öğretmenler disleksiyi; \% 6 hafiza problemi, \% 2'si zihinsel engel, \% 5 konuşmada yaşanan güçlük, \% 1 dikkatsizlik, \% 1 detaylı düşünme rahatsızlığı ve \% 1 oranında ise geçici bir eğitim hastalığı olarak görürken \% 4'ü ise disleksiyi hiç bilmediğinden bahsetmiştir. Buradan çıkan sonuç öğretmenlerin sadece \% 25'i disleksiyi tanırken \% 75'i tanıyamamaktadır.

Öğretmenlerin verdikleri diğer cevaplara örnekler ise şunlardır:

Konuşma ve dil problemidir (SÖ)

Konuşma becerisi eksikliğidir (RÖ)

Bir çeşit zihinsel engeldir (SÖ)

Her şeyi unuturlar. Öğrenmede güçlüktür (SÖ)

Unutmaya bă̆ll öğrenme bozukluğudur (SÖ)

Hafıza, dil ve konuşma ile ilgili bozukluklardır (ÖEÖ)

Verilen birden fazla komutu zihinde yapılandıramamaktır, bir çeşit öğrenme güçlüğ̈̈dür (SÖ)

Bir konuyla ilgili daha detaylı düşünebilme rahatsızlı̆̆ıdır (SÖ)

Geçici bir ĕgitim hastalı̆̆ıdır (TÖ)

Öğretmenlere sorulan “Kendinizi disleksi bilgisi konusunda yeterli görüyor musunuz?” sorusuna verdikleri cevaplar Tablo 8'de verilmiştir.

Tablo 8

Ögretmenlerin Disleksi Konusunda Kendilerini Yeterli Hissetmeleri

\begin{tabular}{lll}
\hline & $f$ & $\%$ \\
\hline Disleksi Bilgilerini Yeterli Görenler & - & - \\
Disleksi Bilgilerini Yeterli Görmeyenler & 72 & 100
\end{tabular}

Öğretmenlerin \% 100'ü kendilerini disleksi konusunda yeterli görmediklerini belirtmişlerdir. Öğretmenlerin, disleksinin kaynağına ilişkin bilgilerinin ne olduğunu ölçmek amacıyla sorulan "Disleksinin nedenleri nelerdir?" sorusuna verilen cevaplar ise Tablo 9'daki gibidir.

Öğretmenlerin \% 23'ü disleksinin genetik nedenlerden kaynaklanan bir problem olduğunu düşünmektedir. Toplam 17 öğretmenin 13'ü (1'i lisansüstü, 2'si ön lisans) sınıf öğretmeni (\% 18), 2'si Türkçe öğretmeni (\% 2.7), 1’i rehber (\% 1.3) ve 1'i özel eğitim öğretmenidir (\% 1.3).

Öğretmenlerin \% 47'si disleksinin nedeninin ne olduğunu bilmediklerini söylemiştir. Bu öğretmenlerin 18'i (1'i lisansüstü) sınıf öğretmeni (\% 25), 6'sı okul öncesi (\% 8.3), 3'ü Türkçe (\% 4.1), 4'ü (1'i lisansüstü) rehberlik (\% 5.5) ve 3’ü özel eğitim öğretmenidir (\% 4.1).

Disleksinin kaynağı olarak beyin/nörobiyolojik nedenleri görenlerin oranı \% 5 (1'i, sınıf öğretmeni, 1'i okulöncesi ve 1'i özel eğitim), zekâ geriliği olarak yorumlayanlar \% 5 (2'si sınıf öğretmeni, 1'i rehber öğretmen), psikolojik nedenlere bağlayanlar ise \% 5'dir (1'i sınıf öğretmeni, 2'si okulöncesi, 2'si Türkçe öğretmeni). 
Tablo 9

Ögretmenlere Göre Disleksinin Nedenleri

\begin{tabular}{|c|c|c|c|c|c|c|c|}
\hline & & Sinif & $\begin{array}{c}\text { Okul } \\
\text { Öncesi }\end{array}$ & Türkçe & Rehberlik & $\begin{array}{c}\text { Özel } \\
\text { Eğitim }\end{array}$ & Toplam \\
\hline $\begin{array}{l}\text { Doğum öncesi, anı ve } \\
\text { sonras1 }\end{array}$ & $\begin{array}{l}f \\
\%\end{array}$ & $\begin{array}{c}5 \\
6.9\end{array}$ & $\begin{array}{c}1 \\
1.3\end{array}$ & $\begin{array}{l}- \\
-\end{array}$ & $\begin{array}{l}- \\
-\end{array}$ & $\begin{array}{l}- \\
-\end{array}$ & $\begin{array}{c}6 \\
8.3\end{array}$ \\
\hline Genetik & $\begin{array}{l}f \\
\%\end{array}$ & $\begin{array}{c}13 \\
18.05\end{array}$ & $\begin{array}{l}- \\
-\end{array}$ & $\begin{array}{c}2 \\
2.7\end{array}$ & $\begin{array}{c}1 \\
1.3\end{array}$ & $\begin{array}{c}1 \\
1.3\end{array}$ & $\begin{array}{c}17 \\
23.6\end{array}$ \\
\hline Nörobiyolojik & $\begin{array}{l}f \\
\%\end{array}$ & $\begin{array}{c}1 \\
1.3\end{array}$ & $\begin{array}{c}1 \\
1.3\end{array}$ & $\begin{array}{l}- \\
-\end{array}$ & $\begin{array}{l}- \\
-\end{array}$ & $\begin{array}{c}1 \\
1.3\end{array}$ & $\begin{array}{c}3 \\
4.1\end{array}$ \\
\hline Zekâ Geriliği & $f$ & $\begin{array}{c}2 \\
2.7\end{array}$ & $\begin{array}{l}- \\
-\end{array}$ & $\begin{array}{l}- \\
-\end{array}$ & $\begin{array}{c}1 \\
1.3\end{array}$ & $\begin{array}{l}- \\
-\end{array}$ & $\begin{array}{c}3 \\
4.1\end{array}$ \\
\hline Psikolojik & $f$ & $\begin{array}{c}1 \\
1.3\end{array}$ & $\begin{array}{c}2 \\
2.7\end{array}$ & $\begin{array}{c}2 \\
2.7\end{array}$ & $\begin{array}{l}- \\
-\end{array}$ & $\begin{array}{l}- \\
-\end{array}$ & $\begin{array}{c}5 \\
6.9\end{array}$ \\
\hline Dikkatsizlik & $f$ & $\begin{array}{l}- \\
-\end{array}$ & $\begin{array}{c}1 \\
1.3\end{array}$ & $\begin{array}{l}- \\
-\end{array}$ & $\begin{array}{l}- \\
-\end{array}$ & $\begin{array}{l}- \\
-\end{array}$ & $\begin{array}{c}1 \\
1.3\end{array}$ \\
\hline İletişimsizlik & $\begin{array}{l}f \\
\%\end{array}$ & $\begin{array}{l}- \\
-\end{array}$ & $\begin{array}{l}- \\
-\end{array}$ & $\begin{array}{c}1 \\
1.3\end{array}$ & $\begin{array}{l}- \\
-\end{array}$ & $\begin{array}{l}- \\
-\end{array}$ & $\begin{array}{c}1 \\
1.3\end{array}$ \\
\hline Alg1sı ile İlgili & $\begin{array}{l}f \\
\%\end{array}$ & $\begin{array}{l}- \\
-\end{array}$ & $\begin{array}{c}1 \\
1.3\end{array}$ & $\begin{array}{l}- \\
-\end{array}$ & $\begin{array}{l}- \\
-\end{array}$ & $\begin{array}{l}- \\
-\end{array}$ & $\begin{array}{c}1 \\
1.3\end{array}$ \\
\hline Sebepsiz & $\begin{array}{l}f \\
\%\end{array}$ & $\begin{array}{l}- \\
-\end{array}$ & $\begin{array}{c}1 \\
1.3\end{array}$ & $\begin{array}{l}- \\
-\end{array}$ & $\begin{array}{l}- \\
-\end{array}$ & $\begin{array}{l}- \\
-\end{array}$ & $\begin{array}{c}1 \\
1.3\end{array}$ \\
\hline Bilmiyorum & $\begin{array}{l}f \\
\%\end{array}$ & $\begin{array}{l}18 \\
25\end{array}$ & $\begin{array}{c}6 \\
8.3\end{array}$ & $\begin{array}{c}3 \\
4.1\end{array}$ & $\begin{array}{c}4 \\
5.5\end{array}$ & $\begin{array}{c}3 \\
4.1\end{array}$ & $\begin{array}{c}34 \\
47.2\end{array}$ \\
\hline
\end{tabular}

Doğum anında, sırasında, sonrasında yaşanan sorunlardan kaynaklandığını düşünen öğretmenlerin oranı \% 6 (5’i sınıf öğretmeni, 1’i okulöncesi öğretmeni), dikkatsizliğe bağlayanlar \% 1 (1’i okul öncesi öğretmeni), iletişimsizlik olarak görenler \% 1'dir (1'i Türkçe öğretmeni). Bireyin algısı ile ilgili problemleri neden olarak görenler \% 1 (1'i okul öncesi öğretmeni) iken, herhangi bir sebebinin olmadığını düşünenler ise \% 1 oranındadır (1'i okulöncesi öğretmeni). Bu soruya verilen cevaplar ise şu şekildedir:

Kesin bilinmemekle beraber beynin bir kısmının hasar görmesi veya gereğince çalışmaması sonucu oluşur (Ö̈Ö)

Kalıtsal olabilir (SÖ)

Tam nedenini bilmemekle beraber nörolojik olduğunu düşünüyorum (ÖEÖ)

Doğum sırasında veya öncesinde o kişinin beynin bazı bölgelerin zarar görmesi (SÖ)

Zekâ geriliği ile bă̆lantısı olabileceği gibi beyin loblarından da kaynaklanabilir (RÖ)

Önyargl, korku olabilir (TÖ)

İletişim süreçlerinin, dinleme ile ilgili süreçlerin olumlu şartlar altında gerçekleşmemesi (TÖ)

Aile şiddeti, yetersiz ilgiden kaynaklanmaktadır (OÖÖ)

Psikolojiktir, aşırı heyecandan kaynaklanır (SÖ)

Çocuğun algısı ile alakalıdır (OÖÖ)

Kültürel yapı ve zekâ geriliği ile alakalı olduğunu düşünüyorum (SÖ)

Belli bir sebebinin olduğunu düşünmüyorum (OÖÖ)

Öğretmenlere sorulan “Sınıfınızdaki disleksili öğrencileri tanılayabilir misiniz?” sorusuna verilen cevaplar ise şu şekildedir: 
Tablo 10

Ögretmenlerin Disleksili Öğrencileri Tanılayabilmeleri

\begin{tabular}{lcc}
\hline & $f$ & $\%$ \\
\hline Evet, tanılayabilirim. & 25 & 34.7 \\
Hayır, tanılayamam. & 47 & 65.2 \\
\hline
\end{tabular}

Öğretmenlerin \% 34'ü disleksili bir öğrenciyi fark edip tanılayabileceğini söylerken, \% 65'i ise tanılayamayacağını söylemiştir.

\section{Öğretmenlerin Disleksili Öğrencilere Verilecek Eğitimle İlgili Yeterlilikleri}

Öğretmenlere sorulan “Disleksili öğrencilerin ihtiyaçlarını karşılayacak eğitim yöntemlerini biliyor musunuz?" sorusuna verdikleri cevaplar Tablo 11'deki gibidir:

Tablo 11

Öğretmenlerin Disleksi Ĕ̆itim Yöntemlerine İlişkin Bilgileri

\begin{tabular}{lcc}
\hline & $f$ & $\%$ \\
\hline Disleksi eğitim yöntemlerini bilenler & - & - \\
Disleksi eğitim yöntemlerini bilmeyenler & 72 & 100 \\
\hline
\end{tabular}

Öğretmenler \% 100 oranında "Hayır" cevabı vererek, disleksili öğrencilerin eğitim ihtiyaçlarına yönelik eğitim yöntemlerini bilmediklerini söylemişlerdir. Öğretmenlere sorulan "Disleksili öğrencileriniz için, diğer öğrencilerinize uyguladığınız okuma programlarından farklı bir program uyguluyor musunuz?" sorusuna verilen cevaplar ise, Tablo 12'de görüldüğü üzere, bir önceki soruya verilen cevaba paralellik göstermektedir.

Tablo 12

Öğretmenlerin Disleksili Öğrencilere Diğer Öğrencilerden Farklı Okuma Ĕ̆itimi Uygulama Durumu

\begin{tabular}{lcc}
\hline & $f$ & $\%$ \\
\hline Farklı bir program uygulayanlar & - & - \\
Farklı bir program uygulamayanlar & 72 & 100 \\
\hline
\end{tabular}

Öğretmenlerin \% 100'ü disleksili öğrencilerin okuma ihtiyaçlarını diğer öğrencilerle aynı görmekte ve farklı bir program uygulamamaktadır. Öğretmenlerin bu öğrenciler için yaptıkları eğitim uygulamalarına verdikleri cevaplar şu şekildedir:

Rahatsızlık yaşadı̆̆ harflerle ilgili metinler bulup çalıştırıyorum (SÖ)

Bol tekrar yaptırlyorum (SÖ)

Etkinliklere dikkat çekerek ögretim uyguluyorum (SÖ)

Farklı olması gerekir ama okulda uygulamıyorum (RÖ)

Farkl yöntemler vardır ama uygulamıyorum (SÖ)

Disleksili öğrencim olmadı̆̆ı için bu uygulamaları bilmiyorum (ÖEÖ)

Öğretmenlerin öğrencilere ayırdıkları zaman ve niteliği hakkında bilgi edinebilmek amacıyla "Disleksili öğrencilerinize uyguladığınız okuma eğitimlerini ne zaman ve hangi derslerde yapıyorsunuz?" Sorusu sorulmuştur. Bu soruya verilen cevaplar Tablo 13’teki gibidir:

Tablo 13

Öğretmenlerin Disleksili Ögrrencilerle İlgilendikleri Zamanlar

\begin{tabular}{lcc}
\hline & $f$ & $\%$ \\
\hline Öğle arasında & 3 & 4.1 \\
Beden eğitimi, müzik, görsel sanatlar gibi diğer derslerde & 4 & 5.5 \\
Serbest etkinlik saatlerinde & 3 & 4.1 \\
Ders içinde & 4 & 5.5 \\
Yapmiyorum & 58 & 80.5 \\
\hline
\end{tabular}

Öğretmenlerin \% 4'ü disleksili öğrencilere okuma eğitimini öğle aralarında, \% 5’i beden eğitimi, müzik, görsel sanatlar gibi derslerde, \% 4'ü öğrencinin serbest kaldığı etkinlik saatlerinde verdiklerinden bahsetmiştir. Öğretmenlerin sadece \% 5'i ders içinde bu öğrencilerle de ilgilendiklerinden bahsederken, \% 80’i ise hiç eğitim vermediklerini söylemişlerdir. Öğretmenlerin verdikleri cevaplar şu şekildedir: 
Ders içerisinde yanıma getirerek okuma ve yazma çalışmast yaplyoruz (SÖ)

Türkçe dersinde eğitim veriyorum (SÖ)

Beden eğitimi, müzik gibi boş derslerde çalışlyoruz (SÖ)

Serbest okuma saatlerinde çalışlyorum (SÖ)

Öğle aralarında çalışıyoruz (SÖ)

Herhangi bir eğitim yapmiyorum (SÖ)

Sinı öğretmeni olarak, İngilizce ve Din Kültürü derslerinde boşa çıktığım zamanlarda (SÖ)

Uygun derslerde rehberlik servisinde yapıyorum (RÖ)

Öğretmenlerin disleksili öğrencilerin eğitimlerinin hangi yolla verilmesi gerektiğine ilişkin görüşlerini ölçmek amacıyla "Bu öğrencilere verilmesi gereken eğitimlerin sınıf içinde kaynaştırma eğitimi yoluyla mı, sınıf dışında destek eğitim odalarıyla mı yapılması gerektiğini düşünüyorsunuz?" sorusu sorulmuştur ve verdikleri cevaplar Tablo 14'teki gibidir:

Tablo 14

Öğretmenlerin Disleksili Öğrenciler Iç̧in Kaynaştırma ve Destek Odası Ĕ̆itimi Görüşleri

\begin{tabular}{lcc}
\hline & $f$ & $\%$ \\
\hline Destek Eğitim & 26 & 36.1 \\
Kaynaştırma Eğitimi & 6 & 8.3 \\
Her İkisi de & 28 & 38.8 \\
Kararsız & 12 & 16.6 \\
\hline
\end{tabular}

Öğretmenlerin \% 36'sı destek eğitim odalarıyla verilecek eğitimi desteklerken, \% 8'i kaynaştırma eğitimini bu öğrenciler için faydalı bulmaktadır. Öğretmenlerin \% 16'sı kararsızken, \% 38'i ise her ikisinin de uygulanacağı bir eğitimi desteklemektedir. Öğretmenler her ikisinin uygulanacağı eğitimle ilgili görüş belirtirken bazıları öğrencinin okuma ihtiyaçları giderilene kadar destek eğitim odalarıyla eğitim alıp sonra kaynaştırma eğitiminin devam etmesinden yanayken bazıları da akademik becerilerle ilgili derslerde destek eğitim odalarında diğer derslerde ise kaynaştırma yoluyla sınıf içinde bulunmaları gerektiğinden bahsetmişlerdir. Öğretmenlerin bu soruya verdikleri cevaplar şu şekildedir:

Sinıf içinde sosyalleşmesi önemlidir. Fakat akademik becerilerde destek eğitim odasında eğitim almalıdir (ÖEÖ)

Destek eğitim odasından yanayım. Çünkü daha fazla zaman ve uzmanlık istiyor bu eğitim (SÖ)

Sinıf dışında destek eğitim odasında verilmesi daha iyi olur. Çünkü sesleri verirken dikkati dağıllyor. Bana değil sınıftaki arkadaşlarına odaklaniyor. Bence uyaranların az olduğu bir yerde verilmesi daha uygun olur (SÖ)

Destek eğitim odalarında birebir eğitim daha faydalıdır. Sinıfta kaynaştırma yoluyla eğitim lafta iyi, uygulamada başarısız bir programdir (SÖ)

İkisi birlikte olmalı. Öncelikle ilk zamanlar destek eğitim odalarında daha fazla vakit geçirmeli. Daha sonra kaynaştırma yolu kullanılmalı (OÖÖ)

Kaynaştırma yoluyla yapılması gerektiğini düşünüyorum. Bazen bizden alamadıklarını arkadaşlarından almaya daha hevesli olabiliyorlar (SÖ)

Kaynaşstırma yoluyla yapılması gerektiğini düşünüyorum. Çocuğun destek eğitim odasına çekilerek kendini dışlanmış, damgalanmış hissedeceğine inanıyorum (OÖÖ)

Bence ikisi de olmalıdır. Çünkü kaynaştırma aynı sınıfta sosyalleşmesini sağlayacaktır. Destek eğitim odasında birebir eğitim alarak sorun daha hızlı çözülebilir (RÖ)

Destek eğitim odalarında temel dersler alınabilir. Müzik, beden eğitimi vb. dersler için kaynaştırma eğitimi verilmelidir (SÖ)

Öncelikle destek eğitim odalarında, daha sonra kaynaştırma yoluyla eğitim verilebilir (OÖÖ)

Destek eğitim odalarıyla çünkü kaynaştırmada öğretmen fazla zaman ayıramaz (SÖ) 


\section{Sonuç ve Tartışma}

Çalışmada, öğretmenlerin disleksiye ilişkin eğitim ihtiyaçlarını ortaya koyan önemli bulgulara ulaşılmıştır. Öğretmenlerin yalnızca \% 40'ının üniversite öğrenimleri sırasında disleksi hakkında bilgilendirildiği ve bu bilgilenmelerin ise çoğunlukla, bir veya birkaç ders saatinden oluşan kısa bilgilendirilmeler olduğu ortaya çıkmaktadır. Branş bazında ise en çok rehber öğretmenler \% 83 oranında, okul öncesi öğretmenleri ise \% 61 oranında üniversitede disleksi eğitimi aldıklarından bahsetmiştir. Öğretmenlerin tamamı öğrenme güçlügüne iliş̧in ayrı bir ders almadıklarından bahsetmişlerdir. Disleksi hakkında üniversitede bilgilendiğini söyleyen öğretmenlerden; rehber öğretmenler ve özel eğitim öğretmenleri birkaç derslik kısa bilgilendirildiklerini, sınıf öğretmenleri ve okul öncesi öğretmenleri ise Kaynaştırma Ĕgitimi derslerinde kavramın sadece bahsi geçtiğinden söz etmişlerdir. Öğretmenler \% 95 oranında üniversite eğitimlerinde aldıkları disleksi eğitiminin yeterli olmadığı kanısındadır. Bu noktada eğitimcilerin disleksi hakkındaki farkındalıkları oldukça önemlidir. Gwernan-Jones ve Burden'ın (2010). İngiltere'de aday öğretmenlerle yaptıkları araştırmaya göre öğretmen adayları disleksi bilgilerine güvenmekte ve disleksiye karşı olumlu tutum beslemektedirler. Türkiye'de ise Güngörmüş Özkardeş'in de (2012) ifade ettiği gibi üniversitelerde Rehberlik ve Psikolojik Danışma, Sınıf Öğretmenliği ve Özel Eğitim Öğretmenliği Bölümleri olmasına karşın bu bölümlerde öğrenme güçlüğüyle ilgili ders veren fakültelerin 2007-2008 eğitim-öğretim yılına kadar çok az olduğu, bu dönemden sonra ise PDR bölümlerine Öğrenme Güçlükleri adı altında bir ders konulduğu bilinmektedir. Buna rağmen, araştırmalarda kaynaştırma eğitimi konusunda yetersiz olduklarından bahseden sınıf öğretmenleri, okul öncesi öğretmenleri ve branş öğretmenleri lisans düzeyinde öğrenme güçlüğüne ilişkin bir ders almamaktadırlar (Şekercioğlu, 2010; Battal, 2007).

Üniversitedeki disleksi çalışmaların azlığı, yetişmiş akademik personelin varlığını etkilemekte bu durum ise öğretmen adaylarına bu dersin programlarına konulmasını engellemektedir (Balcı, 2015). Sonuç olarak, bu alanda yeterince bilgi sahibi olamayan öğretmenlerin meslekleri içerisinde, kendilerini bu konuda eksik hissetmeleri kaçınılmaz bir gerçektir. $\mathrm{Bu}$ çalışmanın da açıkça ortaya koyduğu gibi öğretmenler yükseköğrenimleri sırasında genelde öğrenme güçlüğü özelde ise disleksi konusunda yeterince bilgilendirilmemektedirler.

Öğretmenlerin mesleklerine atandıktan sonra da disleksi hakkında yeterince bilgilendirilmedikleri ortaya çıkmıştır. Öğretmenlerin \% 97'si, hizmet içi eğitimlerde disleksi hakkında bilgilendirilmediklerini söylemişlerdir. Öğretmenlerin \% 30’u disleksi kavramını daha önce hiç duymadıklarından bahsetmişlerdir. Hem yükseköğrenimleri hem de hizmet içinde yeterince disleksi eğitimi almayan öğretmenlerin \% 25'inin bu kavramı bir filmden öğrendikleri ortaya çıkmıştır. Daha önce izledikleri Yerdeki Yıldızlar/Her Çocuk Özeldir adlı bir Hint Filmiyle bu kavram hakkında haberdar olduklarından bahsetmişlerdir. Yıldırım, Tüzel ve Yıldırım (2016), çalı̧̧malarında eğitimcilerin bu filmi, bireysel farklılıkları konu alan eğitici bir film olarak değerlendirdiklerinden bahsetmiş, bu tür filmlerin öğretmen eğitiminin bir parçası olarak kullanılabileceği üzerinde durmuştur. Bununla birlikte araştırmada çıkan sonuç oldukça ilginçtir çünkü öğretmenler disleksiye öğretmen ve hizmet içi eğitimleri sırasında değil sosyal hayatta izledikleri bir film ve internetten yaptıkları araştırmalarla öğrenmektedir. Sonuç olarak disleksi konusunda eğitimcilerin tek başlarına bırakıldığı anlaşılmaktadır. Ülke çapında bazı ilçe milli eğitim müdürlüklerinin hizmet içi eğitim hizmetleriyle özel öğrenme güçlüğü kursları verdiği bilinmektedir. Bununla birlikte bu kursların sayıları oldukça azdır. Bu kurslarda öğrenme güçlüğü sadece tanıtılmamalı, öğrenme güçlüğüne sahip öğrencilere nasıl müdahale edilmesi gerektiği de paylaşılmalıdır. Bu nedenle, MEB öğretmen eğitimi ve yetiştirme genel müdürlüğü tarafindan hizmet içi eğitim faaliyetlerinde öğrenme güçlüğ̈̈ alanına yönelik bir modül oluşturularak, ülke çapında sertifikasyon sistemiyle bu eğitimin öğretmenlere verilmesi önerilmektedir.

Öğretmenlerin bilgi düzeylerini ölçmek amacıyla sorulan diğer sorularda da görüldüğü üzere bu alandaki bilgileri medyada verilen kulaktan dolma bilgilerden ibarettir. Bu bilgilere öğretmenler genel anlamda internet sitelerindeki yazılı kaynaklardan ulaşmışlardır. Öğretmenlerin \% 26’sı "Disleksi nedir?" sorusuna "Disleksi kelimeleri, harfleri ters görmedir yani ayna görüntüsüdür." cevabını vermiştir. Oysaki disleksili bireylerin geriye okuma yaptığı kanısı bir söylentidir. Shaywitz (2003) bu bireylerin, harfleri ve kelimeleri geriye doğru görüp algıladıklarına dair hiçbir kanıt olmadığından bahsetmektedirler. Yapılan pek çok çalışma ayna görüntüsü adı verilen ama tamamen efsaneden ibaret olan bu okuma türünün disleksiyle ilişkilendirilmesinin yanlış olacağı yönündedir ( Flynn ve Deering, 1989; Akhtar, 2008; Shaywitz ve Shaywitz, 2003). Buna rağmen Washburn, Joshi ve Binks-Cantrell'ın (2011) da kanıtladığı gibi öğretmenlerde disleksinin, fonolojik işlem yetersizliği yerine görsel işlemde yaşanan güçlük olarak algılandığı yaygın bir yanlış düşünce hâkimdir. Bu cevabı veren öğretmenlerin dışında disleksiyi; öğrenememe rahatsızlığı, hafıza problemi, zihinsel engel, konuşmada yaşanan güçlük, dikkatsizlik, detaylı düşünme rahatsızlı̆̆ 1 ve geçici bir eğitim hastalığı gibi doğru olmayan ifadelerle tanılayan öğretmenlerin oranı da oldukça fazladır. Öğretmenlerin sadece \% 25'i disleksiyi doğru tanımlayabilirken \% 75'i yanlış ya da eksik tanımaktadır. Doğru tanımlayanların ise branş bazında özel eğitim, rehber ve sınıf öğretmenleri olduğu görülmektedir. Bununla birlikte disleksiyi tanıma oranı oldukça azdır. Bunun 
sebebi ise özellikle internet araştırmalarında karşılaştıkları bilgiyi kabul etmeleri ve bu bilgileri sorgulayacak eğitimlerinin eksik olmasıdır.

Öğretmenlere sorulan "Kendinizi disleksi bilgisi konusunda yeterli görüyor musunuz?" sorusuna eğitimcilerin \% 100 oranında kendilerini yeterli görmediklerini söylemeleri disleksi konusundaki eğitim ihtiyaçlarını doğrular niteliktedir. Bu durum, eğitim ortamında karşılaştıkları disleksili öğrencileri tespit edebilmelerini ve onlara gerekli eğitim desteğinde bulunmalarını doğrudan etkileyecektir. Öğretmenler de bu doğrultuda cevaplar vererek $\% 65$ oranında disleksili bir öğrenciyle karşılaşmaları durumunda onları tespit edemeyeceklerini söylemişlerdir. Doğan'a (2013) göre de, Türkçe ve sınıf öğretmenleri okuma güçlüğü olan öğrencileri belirlemede yetersiz kalmaktadır. Yapılan bu çalışmada öğretmenlerin \% 100'ü disleksili öğrencilerin ihtiyaçlarını karşılayacak eğitim yöntemlerini bilmediklerini belirtmişler ve yine tamamı disleksili öğrencilerin okuma ihtiyaçlarını diğer öğrencilerle aynı gördüklerini ve farklı bir program uygulamadıklarını söylemişlerdir. Altuntaş (2010) da çalı̧̧masında, sınıf öğretmenlerinin disleksili öğrencilere yönelik özel bir çalışma yapmadıkları, kendilerini disleksi ve bu bireylerin eğitimi konusunda yeterli görmedikleri sonucuna ulaşmıştır. Bu sonuçlardan da anlaşılacağı üzere, disleksili bireyler bu sorunları fark edilmeden, zamanında tanılama yapılmadan ve gerekli eğitimleri görmeden eğitim hayatlarına devam etmeye çalışmaktadırlar. Bu çalışmadan da çıkan sonuç da gösteriyor ki, öğretmenler bu öğrenciler için \%80 oranında ekstra çalı̧̧ma yapmamakta, yapanlar ise Koç'un (2012) da bahsettiği gibi beden eğitimi, müzik gibi derslere ya da öğle aralarına sıkıştırarak eğitim vermeye çalışmaktadır.

Öğretmenlerin, daha düzenli ve profesyonel bir eğitim için önerileri destek eğitim odaları ya da hem destek eğitim odası hem de kaynaştırma eğitiminin bir arada yürütüldüğü bir eğitim anlayışıdır. Sart, Ala, Yazlık ve Yılmaz (2004) da çalışmalarında, öğretmenlerin çoğunluğunun tam zamanlı kaynaştırma yerine yarı zamanlı kaynaştırmanın daha başarılı olacağını düşündüklerinden söz etmektedir. Öğretmenlerin de desteklediği destek eğitim odalarının, Batu'nun (2012) da ifade ettiği üzere uygulamada varlığı oldukça azdır. Bu durumun nedenleri üzerinde durulması ve çözüme kavuşturulması oldukça önemlidir.

Eğitimcilerin az da olsa disleksi kavramını bir şekilde duydukları fakat derinlemesine bilgi sahibi olmadıkları ve bu öğrenciler için neler yapacaklarını bilmedikleri sonucuna ulaşılmıştır. Bu çalışma ışı̆̆ında; disleksili bireylere uygun bir eğitim programı izlenmediğini, dünyada uygulanan eğitim programları hakkında öğretmenlerin yeterince bilgi sahibi olmadıklarını ve bu öğrencilerin eğitiminde belirli bir standardın olmadığını, eğitimlerin öğretmenin vicdanına bırakıldığını ve onların boş kaldıkları zamanda bu öğrencilere eğitim verdiklerini söylemek mümkündür. 


\section{Kaynakça/References}

Akhtar, S. (2008). The nature of developmental dyslexia. (Yayımlanmamış yüksek lisans tezi). Long Island Üniversitesi, New York.

Aladwani, A. M. \& Al Shaye, S. S. (2012). Primary school teachers' knowledge and awareness of dyslexia in Kuwaiti students. Education, 132(3), 499-517.

Altuntaş, F. (2010). Sınıf öğretmenlerinin disleksiye ilişkin bilgileri ve dislektik ögrencilere yönelik çalışmaları. (Yayımlanmamış yüksek lisans tezi). Hacettepe Üniversitesi Sosyal Bilimler Enstitüsü, Ankara.

Bacanlı, H. (2004). Gelişim ve öğrenme. Ankara: Nobel.

Balc1, E. (2015). Amerika Birleşik Devletleri'nde disleksili bireylere uygulanan eğitim ve öğretim programlarının Türkiye'de yapılan çalışmalara katkısı açısından değerlendirilmesi. (Yayımlanmamış Doktora Tezi). Gazi Üniversitesi Eğitim Bilimleri Enstitüsü, Ankara.

Balcı, E. (2017). Disleksi hakkında gerçekler: Disleksi nedir ve ne değildir? Trakya Üniversitesi Sosyal Bilimler Dergisi. 19(1), 1-17.

Battal, İ. (2007). Sinıf ögretmenlerinin ve branş öğretmenlerinin kaynaştırma ĕgitimine ilişkin yeterliliklerinin değerlendirilmesi (Uşak ili örneği). (Yayımlanmamış yüksek lisans tezi). Afyonkarahisar Kocatepe Üniversitesi Sosyal Bilimler Enstitüsü, Afyonkarahisar.

Batu, E. S. (2012). Kaynaştırma ve destek özel ĕgitim hizmetleri, özel eğitime gereksinimi olan öğrenciler ve özel eğitim. Ankara: Pegem A.

Baydık, B., Ergül, C. ve Kudret, Z. B. (2012). Okuma güçlüğü olan öğrencilerin okuma akıcılığı sorunları ve öğretmenlerinin bu sorunlara yönelik öğretim uygulamaları. İlköğretim Online, 11(3), 778-789.

Doğan, B. (2013). Türkçe ve sınıf öğretmenlerinin okuma güçlüğüne ilişkin bilgileri ve okuma güçlüğü olan öğrencileri belirleyebilme düzeyleri. Okuma Yazma Ĕ̆itimi Araştırmaları, 1(1), 20-33.

Ergül, C., Karaman, G., Akoğlu, G., Tufan, M., Sarıca, A. D. ve Kudret, Z. B. (2014). Okul öncesi öğretmenlerinin "Erken Okuryazarlık” kavramına ilişkin bilgi düzeyleri ve sınıf uygulamaları. İlkögretim Online, 13(4), 1449-1472.

Exley, S. (2003). The effectiveness of teaching strategies for students with dyslexia based on their preferred learning styles. British Journal of Special Education, 30(4), 213-220. doi:10.1111/j.09523383.2003.00313.x

Flynn, M. J., \& Deering, M. W. (1989). Subtypes of dyslexia: İnvestigation of border's system using quantitative neurophysiology. Developmental Medicine \& Child Neurology, 31, 215-223. doi:10.1111/j.14698749.1989.tb03981.x

Gwernan-Jones, R., \& Burden, R. L. (2010). Are they just lazy? Student teachers' attitudes about dyslexia. Dyslexia, 16(1), 66-86. doi:10.1002/dys.393

Güngörmüş Özkardeş, O. (2012). Türkiye'de özel öğrenme güçlüğüne ilişkin yapılan uygulamalar. Ístanbul Ticaret Üniversitesi Sosyal Bilimler Dergisi, 21(1), 25-38.

Hellendoorn, J., \& Ruijssenaars, W. (2000). Personal experiences and adjustment of Dutch adults with dyslexia. Remedial and special education, 21(4), 227-239. doi:10.1177/074193250002100405

Humphrey, N. (2003). Facilitating a positive sense of self in pupils with dyslexia: the role of teachers and peers. Support for Learning, 18(3), 130-136. doi: 10.1111/1467-9604.00295

IDEA. (2004). Amerika Birleşik Devletleri kamu hukuku 94-142, Individuals with disabilities education improvement yasası 2004, 108. Amerika Birleşik Devletleri Kongresi.

Ingesson, S. G. (2007). Growing up with dyslexia: Interviews with teenagers and young adults. School Psychology International, 28(5), 574-591. doi:10.1177/0143034307085659 
Karasar, N. (2000). Bilimsel araştırma yöntemleri. Ankara: Nobel Yayın Dağıtım.

Kaptan, S. (1998). Bilimsel araştırma ve istatistik teknikleri. Ankara: Tekışık Web Ofset Tesisleri.

Koç, B. (2012). Sınıf öğretmenlerinin sınıflarındaki öğrenme güçlüğ̈̈ çeken öğrencilerine yönelik özel uygulamalarının incelenmesi. (Yayımlanmamış yüksek lisans tezi). Necmettin Erbakan Üniversitesi Eğitim Bilimleri Enstitüsü, Konya.

Lerner, J. W. (1989). Educational interventions in learning disabilities. Journal of the American Academy of Child \& Adolescent Psychiatry. 28(3), 326-331. doi:10.1097/00004583-198905000-00004

Morgan, W. P. (1896). A case of congenital word blindness. British Medical Journal, 2(1871), 1378. doi:10.1136/bmj.2.1871.1378

Riddick, B., Sterling, C., Farmer, M. \& Morgan, S. (1999). Self-esteem and anxiety in the educational histories of adult dyslexic students. Dyslexia, 5(4), 227-248. doi:10.1002/(SICI)1099-0909(199912)5:4<227::AIDDYS146>3.0.CO;2-6

Sart, H., Ala, H., Yazlık, Ö. ve Yılmaz, F. (2004). Türkiye Kaynaştırma Ĕ̆itiminde Nerede, Ĕ̆itimciye Öneriler, XIII. Ulusal Eğitim Bilimleri Kurultayı, 6-9 Temmuz 2004, İnönü Üniversitesi, Eğitim Fakültesi, Malatya.

Shaywitz, S., \& Shaywitz, B. (2003). Dyslexia (Specific reading disability). Language-cognition, 24(5), 147153. doi:10.1016/j.biopsych.2005.01.043

Shaywitz, S. (2003). Overcoming dyslexia: A new and complete science-based program for reading problems at any level. New York: Alfred A. Knopf.

Snowling, M. (2000). Dyslexia. Oxford: Basil Blackwell.

Şekercioğlu, B. (2010). İlköğretim II. kademe branş öğretmenlerinin kaynaştırma uygulamalarında karşılaştıkları sorunlar ile ilgili görüşleri. (Yayımlanmamış yüksek lisans tezi). Gazi Üniversitesi Eğitim Bilimleri Enstitüsü, Ankara.

Şenel, H. G. (1998). Okuma güçlüğ̈̈ olan ve olmayan ilkokul ögrencilerinin okuma düzeyinin ve dislektik özelliklerinin karşılaştırılması. (Yayımlanmamış doktora tezi). Ankara Üniversitesi Sosyal Bilimler Enstitüsü, Ankara.

Washburn, E. K., Joshi, R. \& Binks-Cantrell, E. S. (2011). Teacher knowledge of basic language concepts and dyslexia. Dyslexia, 17(2), 165-183. doi:10.1002/dys.426

Yıldırım, A. ve Şimşek, H. (2003). Sosyal bilimlerde nitel araştırma yöntemleri. Ankara: Seçkin Yayınları

Yıldırım, N., Tüzel, E. ve Yıldırım, Y.V. (2016). Aamir Khan filmlerinin eğitimsel açıdan incelenmesi: 3 Idiots (3 Aptal) ve Taare Zameen Par (Her çocuk özeldir) üzerine bir değerlendirme. Atatürk Üniversitesi Güzel Sanatlar Enstitüsü Dergisi, (36), 210-244. 